\title{
Computational Image based Approach to study the Impact of Industrial Effluent on Groundwater and River Quality in Ballarpur, Maharashtra State, India
}

\author{
Rakhi Nikhade \\ CSIR-National Environmental \\ Engineering Research Institute \\ (CSIR-NEERI), Nagpur-440020, \\ (Maharashtra), India
}

\author{
Abhay B. Fulke \\ CSIR-National Environmental \\ Engineering Research Institute \\ (CSIR-NEERI), Nagpur-440020, \\ (Maharashtra), India
}

\author{
Shrikant Vyawhare \\ Anacon Laboratories Pvt. Ltd. \\ Nagpur - 440033, (Maharashtra), \\ India
}

\begin{abstract}
The water quality is one of the most important criteria to ascertain its suitability for human beings and irrigation. This paper presents the effects of treated industrial waste water effluent on ground water as well as on surface water. The samples were collected from discharge point of treated industrial effluent in the river, upstream and downstream point of river and analyzed for physico-chemical characteristics such as $\mathrm{pH}$, Electrical conductivity (EC), Total alkalinity (TA), Total acidity, Total hardness (TH), Chemical oxygen Demand (COD), Total Hardness, Chloride (Cl-), Sulfate $\left(\mathrm{SO}_{4}\right)$ and Sodium (Na). For the analysis of effect of effluent on ground water quality, the tube well water at various distance from Wardha River were also collected. The obtained results were compared with WHO (World Health Organization) and BIS (Bureau of Indian Standards) limits. The results show that there is an infiltration of contaminants into the tube wells nearest to the point of discharge.
\end{abstract}

\section{Keywords}

Treated effluent, Physico-chemical characteristics, Infiltration of contaminant

\section{INTRODUCTION}

Industrialization can be considered an enviable option due to its contribution to the national economic growth. However, it exerts considerable pressure upon the natural resources, along with an increased demand for energy. In addition, the waste generated by the industries is a major environmental concern and the disposal of effluents without appropriate treatment could have long term adverse effects [1]. The consequences of industrialization and urbanization leads to spoiling the water. This is observed that ground water get polluted due to increased human population, agricultural runoff, domestic sewage, industrial effluents, addition of various kinds of pollutants and human activities. Due to drinking of contaminated water number of cases of water born diseases has been seen which causes health hazards. Water quality data is essential for the implementation of responsible water quality regulations for characterizing and remediating contamination and for the protection of the health of humans and the ecosystem. Hence it is necessary to test drinking water quality and its suitability for drinking and domestic purposes. It is also necessary to find out various sources of contamination of surface as well as ground water.

\section{MATERIAL AND METHODS}

\subsection{Study Area}

The Ballarpur area considered for the present work. Ballarpur is a municipal council in Chandrapur District in the state of Maharashtra, India. It lies within longitudes $79^{\circ} 21^{\prime} 0^{\prime \prime} \mathrm{E}$ and latitudes $19^{\circ} 50^{\prime} 0^{\prime \prime} \mathrm{N}$, situated $20 \mathrm{~km}$ away from Chandrapur. The town was named Ballarshah after the king Ballarshah. Ballarshah has nine coal mines most of the owned by Public Sector Company, Western coalfields limited, aadditional of coal India limited[2]. Satellite locations of Ballarpur Industrial area are shown in the figure $1 \&$ Ballarpur industrial area shown in figure 2(https://maps.google.co.in/) [3].

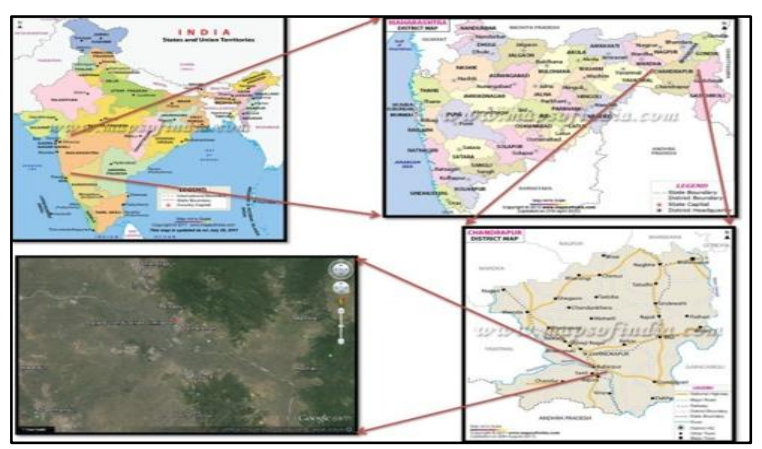

Figure 1: Location of Ballarpur Industrial area.

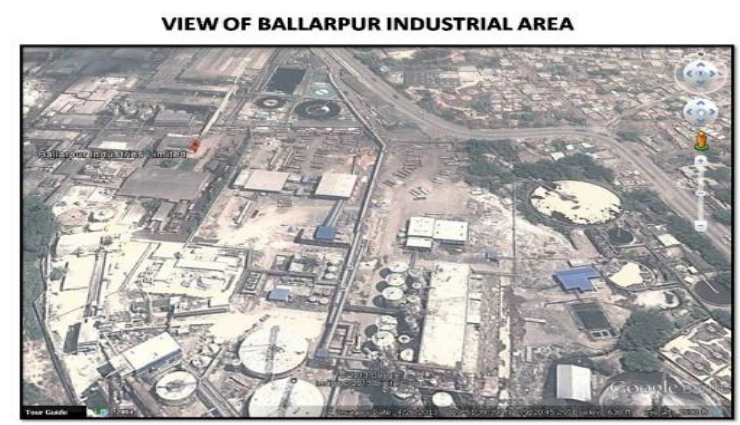

Figure 2: Ballarpur industrial area

The present study deals the assessment of impact of Industrial pollution on River Wardha with reference to physico-chemical and biological parameters and their effects on ground water quality. For the study a Ballarpur industrial area was selected which is situated on the bank of Wardha River in Ballarpur. 


\subsection{Sampling}

Samples from industrial effluent after treatment at discharge point and from river at different points were collected in good quality screw-capped polythene bottles of one liter capacity in the morning hours between 9 to 11 a.m. and labeled properly. For the analysis of effect of effluent on the ground water quality, the tube well water samples at various distances from Wardha River were also collected (Figure 3).

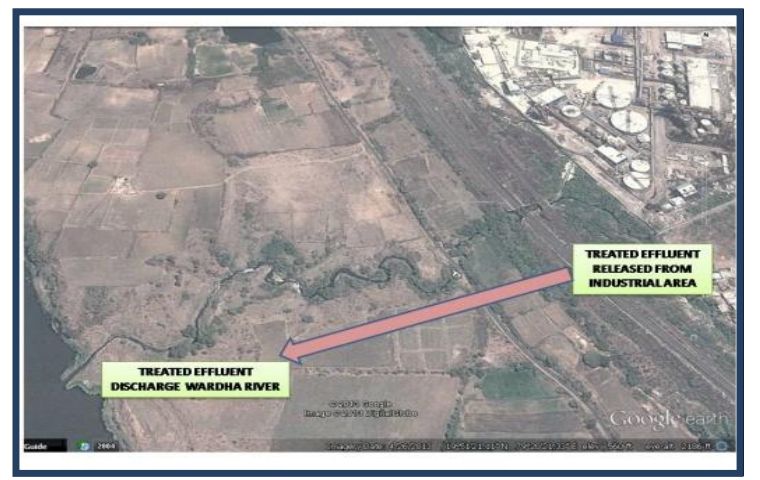

Figure 3: Discharge point of treated industrial effluent in Wardha River

The samples were taken to laboratory as early as possible and kept for further analysis. The parameters like temperature and $\mathrm{pH}$ were measured in the field at the time of sample collection by using thermometer having a quick response with $0.1^{0} \mathrm{C}$ and pocket digital $\mathrm{pH}$-meter while other parameters such as electrical conductivity, Chemical oxygen Demand, total hardness, total alkalinity, total alkalinity, Sodium, Sulfate and chloride were estimated in the laboratory, using standard procedures by APHA [4]. The samples which were collected from different points are described in Table-1

Table-1 Sampling locations

\begin{tabular}{|c|c|c|}
\hline Sr. No. & Sample code & Source \\
\hline 1. & B-1 & $\begin{array}{c}\text { At the point of discharge from } \\
\text { pulp and paper mill to wardha } \\
\text { river }\end{array}$ \\
\hline 2. & B-2 & $\begin{array}{c}\text { At 10 ft distance from the point of } \\
\text { discharge in wardha river. }\end{array}$ \\
\hline 3. & B-3 & From river (Downstream sample) \\
\hline 4. & B-4 & $\begin{array}{c}\text { Tubewell nearest to the point of } \\
\text { discharge. }\end{array}$ \\
\hline 5. & B-5 & $2^{\text {nd }}$ Tubewell \\
\hline 6. & B-6 & $3^{\text {rd tubewell }}$ \\
\hline 7. & B-7 & Upstream sample \\
\hline
\end{tabular}

\section{RESULTS AND DISCUSSION}

The result obtained during the course of the present investigation is summarized in table 2 .
Table-2 Average values of physico-chemical characteristics of water sample

\begin{tabular}{|c|c|c|c|c|c|c|c|c|}
\hline 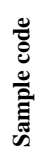 & $\frac{\pi}{2}$ & 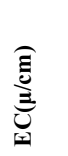 & $\mathbb{E}$ & 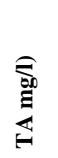 & రิ & 它 & ஸ் & 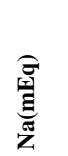 \\
\hline B-1 & 7.4 & 2290 & 450.56 & 420 & 248 & 645.79 & 145 & 180.3 \\
\hline B-2 & 7.4 & 2330 & 478.72 & 410 & 160 & 555.82 & 110 & 31.6 \\
\hline B-3 & 7.6 & 640 & 144.32 & 270 & 16 & 45.92 & 45 & 23.9 \\
\hline B-4 & 6.9 & 1560 & 401.28 & 470 & 16 & 131.95 & 125 & 172.7 \\
\hline B-5 & 6.7 & 1300 & 313.28 & 440 & 8 & 105.96 & 110 & 161.2 \\
\hline B-6 & 6.7 & 1510 & 397.76 & 450 & 4 & 145.95 & 75 & 153.1 \\
\hline B-7 & 7.2 & 1490 & 126.72 & 240 & 9 & 39.98 & 1 & 29.9 \\
\hline
\end{tabular}

The analytical data shows that concentration metal ion, sulfate, chloride was found to be high and it indicates a high degree of contamination with soluble metallic species and other impurity. Various study have reported that even after the primary and secondary treatment industrial effluent contains a concentration of certain contaminants such as sulfate, chlorides, Sodium, hardness etc. that cause harmful effects on flora and fauna. The present study was conducted to evaluate the harmful effects of certain contaminants of the treated industrial effluent on both the river and ground water quality. During the course of the study, the different parameters evaluated were $\mathrm{pH}$, conductivity, alkalinity, acidity, chlorides, COD, Sulfate, sodium and Hardness. The $\mathrm{pH}$ value of water source is a measure of the hydrogen ion concentration in water and indicates whether the water is acidic or alkalinity [5]. Most of the biological and chemical reactions are influenced by the $\mathrm{pH}$ of water system. In the present study all the water samples have $\mathrm{pH}$ values between 6.7-7.6. The standard value of $\mathrm{pH}$ for drinking water by BIS is between 6.5 - 8.5 while, WHO is between 7.0-8.5. If $\mathrm{pH}$ is beyond the permissible limit, it damages the mucous membrane of cells [6]. Electrical conductivity of water is a direct function of its total dissolved salts[7].The WHO permissible limit for electrical conductivity in water is $600 \mu \mathrm{S} / \mathrm{cm}$. Electrical conductivity value of sample at the discharge point is 2290 $\mu \mathrm{S} / \mathrm{cm}$ and $1490 \mu \mathrm{S} / \mathrm{cm}$ in the upstream sample. And the ground water sample ranged from 1300 to $1560 \mu \mathrm{S} / \mathrm{cm}$, indicating the presence of high amount of dissolved inorganic substance in ionized form. When electrical conductivity exceeds $3000 \mu \mathrm{S} / \mathrm{cm}$ affected the germination of almost all the crops and it may result in very less amount of yield. This study has shown that the sulfate concentration in the tube well water closest to the point of discharge was the highest and was found to be $125 \mathrm{mg} / \mathrm{l}$. WHO permissible limit for Sulphate is $200 \mathrm{mg} / \mathrm{l}$. High concentration of sulphate may cause gastro intestinal irritation particularly when magnesium and sodium ions are also present in drinking water resources [8].A high concentration of sulfate also causes laxative effect on cattle and humans. The concentration of sulfate in the ground water away from the point of discharge was found to be progressively lower. The sulfate concentration in ground water sample B-5 and B-6 was found to be $110 \mathrm{mg} / \mathrm{l}$ and 75 $\mathrm{mg} / \mathrm{l}$ respectively and indicated a lessening in the effect of the treated effluent as the distance from discharge point was increased. Similarly, the sulfate concentration in the river sample was found to be highest near the point of discharge and was lower downstream from the point of discharge as observed in sample B-1,B-2 and B-3 having concentration of sulfate as $145 \mathrm{mg} / \mathrm{l}, 110 \mathrm{mg} / \mathrm{l}$ and $45 \mathrm{mg} / \mathrm{l}$ respectively. The 
upstream concentration in the sample B-7 was found to be comparatively lower than the downstream samples. Chloride in the sample B-1, B-2 and B-3 was found to be $645.79 \mathrm{mg} / \mathrm{l}$, $555.82 \mathrm{mg} / \mathrm{l}$ and $45.92 \mathrm{mg} / \mathrm{l}$ respectively. This is clearly shows that as we moved away from the discharge point, the chloride content in the river was get decreased. The chloride in the tube well water samples B-4, B-5 and B-6 was found to be $131.95 \mathrm{mg} / \mathrm{l}, 105.96 \mathrm{mg} / \mathrm{l}$ and $145.95 \mathrm{mg} / \mathrm{l}$. High chloride content in water bodies, harms agricultural crops, metallic pipes and injurious to people suffering due to heart and kidney disease [9]. The permissible limit for chloride is $250 \mathrm{mg} / \mathrm{l}$. The chloride concentrations in upstream water samples were found to be $39.98 \mathrm{mg} / \mathrm{l}$ which is quite low as compared to both in downstream and tube well water sample. The sodium concentration in the sample at the discharge point i.e. sample b-1 was observed as $180.3 \mathrm{mg} / \mathrm{l}$ and as we sampled $10 \mathrm{ft}$ far from the discharge point it was found $31.6 \mathrm{mg} / \mathrm{l}$ and in river $23.9 \mathrm{mg} / \mathrm{l}$.and again it was seen that the sodium concentration in the tube well water samples was increased. For samples B4, B-5 and B-6 sodium concentration was found to be 172.7 $\mathrm{mg} / \mathrm{l}, 161.2 \mathrm{mg} / \mathrm{l}$ and $153.1 \mathrm{mg} / \mathrm{l}$ respectively. This shows that, the infiltration of river water to the ground water increases the concentration of sodium in the tube well nearest to the point of discharge. In upstream water sample, sodium concentration was found to be $29.9 \mathrm{mg} / \mathrm{l}$. High concentration of sodium ion in drinking water may cause heart problems and High sodium ion in irrigation water may cause salinity problems [10]. WHO permissible limit for sodium is $200 \mathrm{mg} / \mathrm{l}$. Alkalinity of water is the measure of the ability to neutralize a strong acid. The bases like carbonates, bicarbonates, hydroxides, phosphates, nitrates, silicates, borates etc are responsible for alkalinity of water [11]. The desirable limit of total alkalinity for drinking water $100 \mathrm{mg} / \mathrm{l}$ (WHO). Alkalinity and Acidity also found to be higher in the discharge point sample i.e.420 $\mathrm{mg} / \mathrm{l}$ and $228 \mathrm{mg} / \mathrm{l}$ respectively and decreases as we sampled the water far from the discharge point. The hardness of treated industrial effluent and tube well water samples is high. The maximum permissible limit of total hardness for drinking purpose is $300 \mathrm{mg} / \mathrm{l}$ (BIS). The hard water can cause the scaling in hot water pipes and utensils. The chemical oxygen demand of treated effluent from industry at discharge point was found to be $248 \mathrm{mg} / \mathrm{l}$ and at upstream point it was found to be $9 \mathrm{mg} / \mathrm{l}$. The chemical oxygen demand values indicate the actual status and extent of pollution. High COD may cause oxygen depletion on account of decomposition of microbes to a level detrimental to aquatic life [12]. COD value is also decreased from discharge point to the point $10 \mathrm{ft}$ far from the discharge point. Overall graphical representation of present work illustrated in figure 4 .
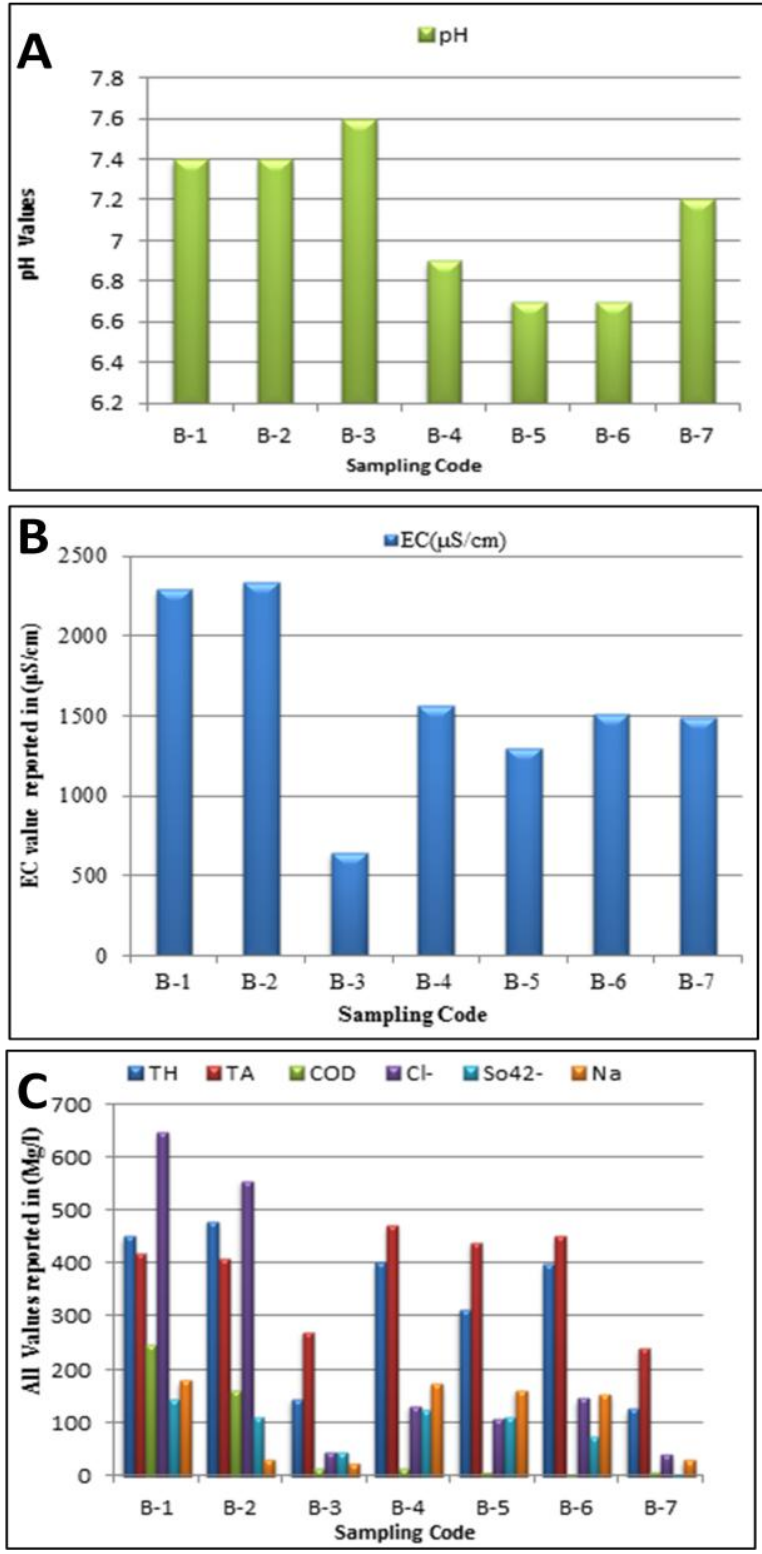

Figure 4: Graphical representation of sampling code (B-1 to B-7) with respect to (A) pH (B) EC and(C) All values reported in $\mathrm{mg} / \mathrm{l}$.

The results of this study correlates with data obtained from other researchers that even at low concentration, contaminant present in treated industrial effluent can cause deleterious effects on river and ground water quality. Certain compounds which are present in the industrial effluent even after the primary and secondary treatment processes can infiltrate ground water which may be used for drinking purposes. The study has shown that, it will be beneficial to design newer treatment strategies for toxic effluent such as pulp and paper mill effluent; such that the toxicity attributed to low level of contaminants can be minimized.

\section{CONCLUSION}

The present study conclusively proved that there is an increase in the concentration of sulfate, chlorides, and hardness in the river water due to the discharge of the treated industrial effluent. The results also showed that there is an infiltration of these contaminants into the tube wells nearest to the point of discharge evidenced by computational map. This may be a serious concern in the long run, since the tube well is used for 
drinking and irrigation purpose. Therefore, there is a need to evaluate new remedies for the treatment of such toxic effluent. This will help to minimize or attenuate the harmful effects on human and environmental health and will also help to retain the river and ground water quality as well as avoid deterioration of soil quality.

\section{REFERENCES}

[1] Lata, K., Kansal.A.,Balakrishnan, M., Rajeshwari, K.V., Kishore,V.V.N. 2002. "Assessment of biomethanation potential of selected industrial organic effluents in India",Resources, Conservation and Recycling Vol. 35. pp 147-161

[2] Das, N.C., 2013. " Physico-Chemical Characteristics of Selected Ground Water Samples of Ballarpur City of Chandrapur District, Maharashtra, India',International Research Journal of Environment Sciences.Vol. 2(11), pp 96-100.

[3] https://maps.google.co.in/

[4] APHA, American Public Health Association. 1995. "Standard Methods for Estimation of water and wastewater", AWWA, Water Pollution Control Federation, New York, 19.

[5] Hanipha, M and Hussain, A. 2013. "Study of ground water quality at Dindigul town, Tamilnadu, India", Int. Res. J. Environment Sci. Vol. 2 (1), pp 68-73.
[6] Nishtha, K., Lokhande, R. S., Dhar, J. K. 2012. "Physicochemical, bacteriological and pesticide analysis of tap water in Millennium city Gurgoan, Haryana, India', Int. Res. J. Environment Sci. Vol.1 (2), pp 1-7.

[7] Pradeep, J. K.1998. "Hydrology and quality of ground water Hirapur district, Sagar (M.P.)", Pollution Research. Vol.17 (1), pp 91-94.

[8] Gupta,I., Salunkhe.A. , Rohra, N., Kumar, R. 2011. "Groundwater quality in Maharashtra, India, Focus on Nitrate pollution", Journal of Environmental Science and Engineering.Vol. 43(4), pp 453-462.

[9] Chapolikar, A. D., Ubale M. B. 2010. "A correlation study on physico-chemical characteristics of ground water in Thane- Belapur industrial area, Mumbai', Current World Environment. Vol. 5(1), pp 67-71.

[10] Dilip, B. P., Rajndra, V. T., Rewatkar, S. B. 2001. "Physicochemical characterstics of ground water of Armori town of Gadchiroli district, Maharashtra, India', Poll. Res. Vol. 20(2), pp 207-209.

[11] WHO. 2004. "International standards for drinking water, World Health Organization, Geneva', pp 55-79

[12] Sivakumar, A. A.andJaganathan, R. 2002. "Hydrology of River Bhavani, Tamilnadu, India”, Ecology and conservation of lakes, reservoirs and rivers.1246. 